\title{
Anomaly of Weather Conditions Over the Indian Ocean and the Formation of Hurricane Chapala
}

\author{
Yehia Hafez \\ Department of Meteorology, King Abdulaziz University, \\ Jeddah, Saudi Arabia
}

\begin{abstract}
The present work studies the relation between the exist of anomaly weather conditions and the formation of hurricane Chapala.NCEP/NCAR reanalysis daily data composites for the meteorological parameters has used. The anomaly and correlation coefficients techniques have been used. The results revealed that a positive extreme of sea surface temperature, surface air temperature and meridional wind over the Indian ocean existed during the duration of the hurricane Chapala. Meanwhile, an extremely negative of the stream function and outgoing longwave radiation has been exist. Moreover, there is a significant correlation coefficient between anomaly of the stream function, sea level pressure and wind over the Indian Ocean and the strong wind of hurricane Chapala. Through the period of study (28 October - 3 November 2015) the extreme weather conditions over the Indian ocean create of hurricane Chapala over the Arabian Sea.
\end{abstract}

Keywords: Hurricane Chapala, Weather conditions, wind, SST, OLR, SF, MSLP, Arabian Sea

\author{
Abbreviations: \\ SST: Sea Surface Temperature \\ SAT: Surface Air Temerature \\ MSLP: Mean Sea Level Pressure \\ PRE: Precipitation Rate \\ OLR: Out Longwave Radiation \\ SF: Stream Function \\ VW: Vector Wind \\ ZW: Zonal Wind \\ MW: Meridional Wind \\ TIO: Tropical Indian Ocean \\ ITCZ: Inter Tropical Convergence Zone
}

\section{INTRODUCTION}

Extremely severe cyclonic storm, hurricane Chapala, was the second strongest tropical cyclone on record in the Arabian Sea (Joint Typhoon Warning Center (JTWC) 2015). It is developed on 28 October in western India. The duration of this hurricane is a seven days. On 3 November, Chapala made landfall near Al Mukalla, Yemen. It is the strongest storm that strikes Yemen on the record. However, on average, there exist from one to two tropical cyclones over the Arabian Sea each year. The year-to-year changes in weather conditions in Arabian tropical cyclones during the pre- and post monsoon periods are elucidated (Evan and Camargo 2011). The hurricane existence over the Arabian Sea became more frequent through the last two decades. Whereas, over the Arabian Sea, in the year of 2007, hurricane Gonu was developed. It is found that, for Gonu, the maximum wind at the surface is more than 140 Knots. After that time of the year of 2010, Hurricane Ph et developed in the Arabian Sea region. Chapala and Megh are the recent hurricanes that develop in the Arabian Sea. It reachesits 
peak intensities of 130 knots and 110 knots respectively. The track of these two hurricanes is approximately the westerly track. Hurricane Chapala passed over Socotra before making landfall in central Yemen (Annual tropical cyclones report 2016). It causes strong damage and disaster, mainly on Socotra. However, organized convection in the tropics occurs mainly in the intertropical convergence zone (ITCZ). The ITCZ is the dominant of the atmospheric circulation system controlling the Tropical Indian Ocean (TIO) climates. Whereas, the ITCZ is located farther south compared to the eastern TIO (Jury et al., 1994; Schott et al., 2009; Vialard et al., 2011; Gong et al., 2013a). The ITCZ appears as a sharp zonally band of cloudiness at low latitudes near the equator (Hafez 2012). The outgoing longwave radiation (OLR) indexing the zones of convection near the equator. Whereas the convection region is a region which has a low OLR (Gadgil and Guruprasad 1990). The TIO ITCZ concept has been very important since the Indian monsoons co-vary closely with it. Whereas, the TIO ITCZ tends to be enhanced along the relatively warmer hemisphere (Broccoli et al., 2006; Kang et al., 2008; Chiang and Friedman, 2012; Frierson and Huang, 2012). The regional air-sea interactions play an important role in the variation of the ITCZ. The feedbacks between the surface wind and sea surface temperature (SST) are key to sustaining for the latitudinal inconsistency of the SST gradients (Xie and Philander, 1994; Philander et al., 1996). Sato et al. (2007) state that the surface wind relevant SST and upwelling influence of the ITCZ precipitation in the northern TIO in autumn. There are several scientific literatures studying the extreme abnormal weather conditions [e.g. (Cohen et al., 2001; Hafez 2007, 2008, 2012 and Rosting and Kristjansson 2008)]. In addition to that,the identification, oscillations, and influence of the ITCZ in the atmospheric weather conditions had studied by (Bates 1970; Pike 1972; Citeau 1988b; Gadgil and Guruprasad 1990; Waliser 1992, 1994; Hess et al., 1993; Philander et al., 1996; Kraus 1997; Sultan and Janicot 2000; Hafez 2003; Broccoli et al., 2006; Raymond 2006 and recently by Hafez and Almazroui 2016). Through of the monsoon transition, the high-SST region forms mainly in early November. The low SST along of the equator exists with the upwelling of the subsurface water Sato et al., (2007). The global distributions of the ITCZ for October month show that there is a splitting of the ITCZ mainly over the Indian Ocean, Atkinson, (1971). The aim of the present study is to find out the relationship between the anomaly of weather conditions over the Indian Ocean and the formation of hurricane Chapala in the Arabian Sea region.

\section{MAterials AND Methods}

The meteorological parameters daily data and satellite images through the period 28 October -3 November 2015 are used in the present study. These data sets obtained from the Indian Meteorological Department (IMD) and from the Joint Typhoon Warning Center JTWC. Moreover, the composites of daily data of NCEP/NCAR reanalysis have been used. The meteorological parameters (mean sea level pressure, surface air temperature, sea surface temperature, zonal and meridional wind, stream function, precipitation rate, and outgoing longwave radiation) over the domain of study $\left(40^{\circ} \mathrm{N}-40^{\circ} \mathrm{S}\right)$ latitudes and $\left(180^{\circ} \mathrm{W}-180^{\circ} \mathrm{E}\right)$ longitudes has been used. The NCEP/NCAR gridded meteorological data are with temporal interpolation of 2.5 degree latitude $\times 2.5$ degree longitude global grid $(144 \times 73)\left[\left(90^{\circ} \mathrm{N}-90^{\circ} \mathrm{S}\right),\left(0^{\circ} \mathrm{E}-357.5^{\circ} \mathrm{E}\right)\right]$ (Kalnay, et al., 1996). The normal mean for the values of meteorological parameters has taken for the period (1981-2010). The data sets analyzed using of the time series and anomaly methodology. In addition, a linear correlation coefficient and significant level method according to the Pearson correlation method are used (Kendall, and Stuart 1973).

\section{The Formation of Hurricane Chapala}

Chapala started as a tropical depression over the southwest of India. It is initiated on October 28 of the year of 2015. Cyclone Chapala is rapidly intensified westward through the northern Indian Ocean. Chapala has quickly strengthened into a powerful cyclone to become a hurricane category. This storm rapidly intensified from wind speeds of $40 \mathrm{mph}$ on 28 October 2015 to reach to its maximum wind speed of $155 \mathrm{mph}$ on 30 October 2015. The storm has weakened slightly to $150 \mathrm{mph}$ through but remains in Category 4 hurricane. According to the Saffir-Simpson Hurricane Wind Scale of hurricanes (Saffir 1973 and Simpson 1974). The surface track of hurricane Chapala is approximately a complete westward track. Figure (1) illustrates the daily track of its from 28 October to 3 November 2015 over the Arabian Sea. 


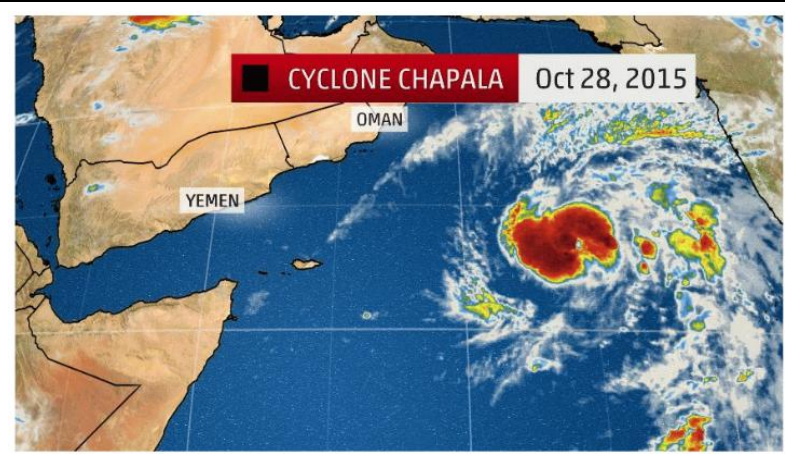

(a)

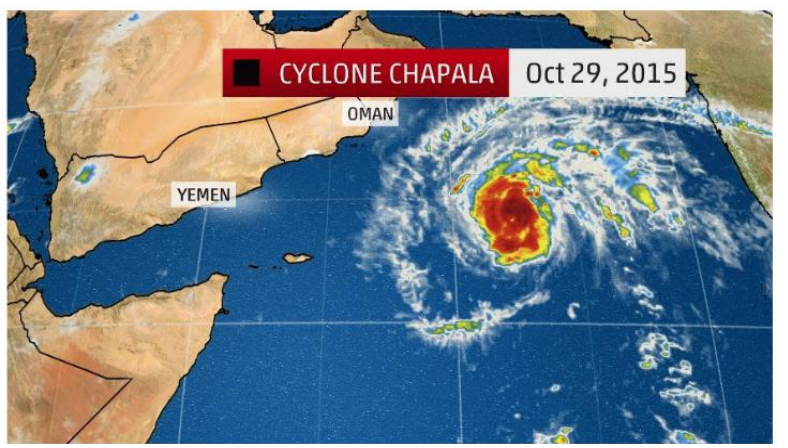

(b)

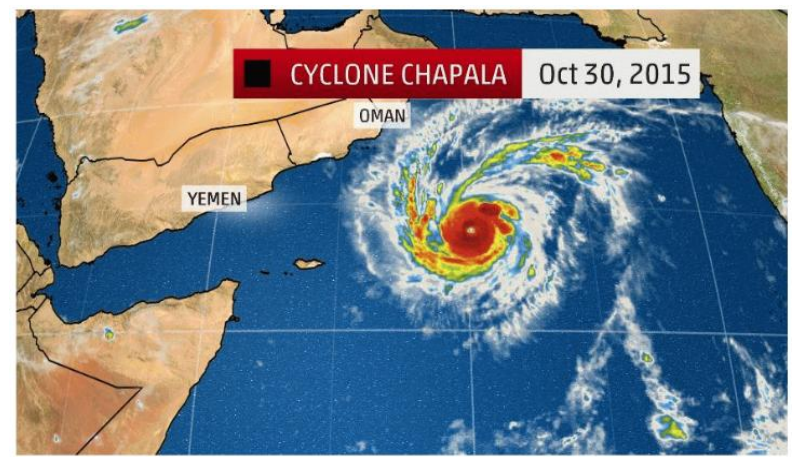

(c)

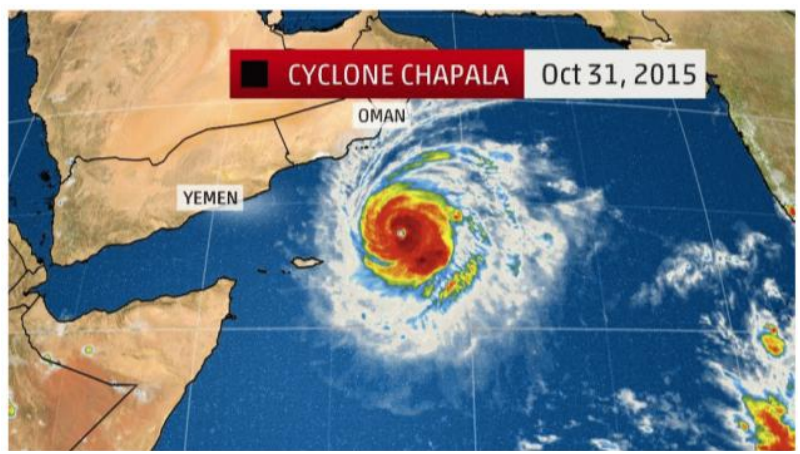

(d)

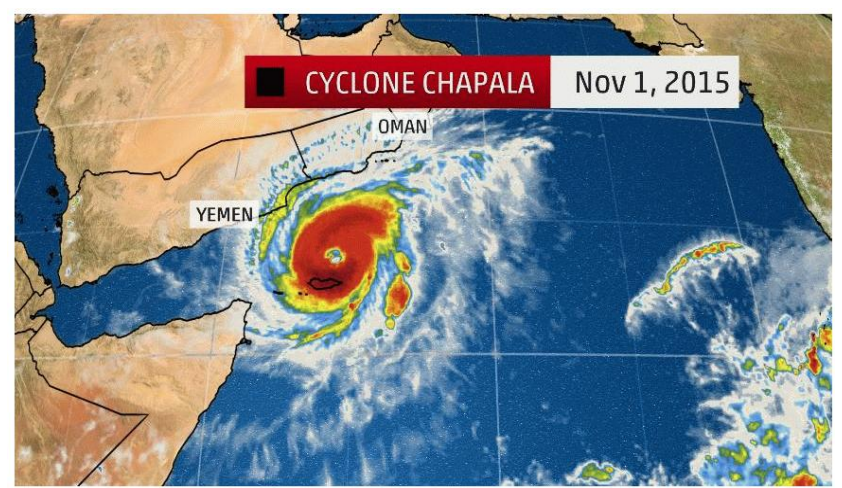

(e) 


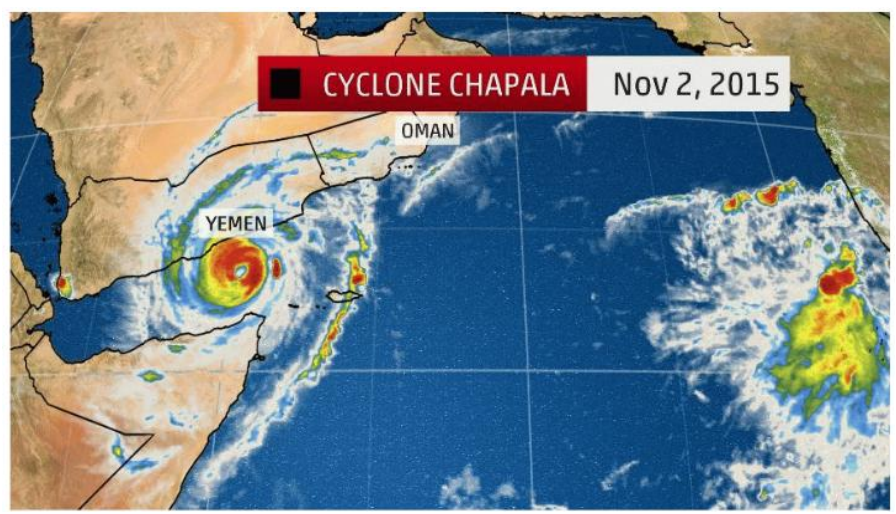

(f)

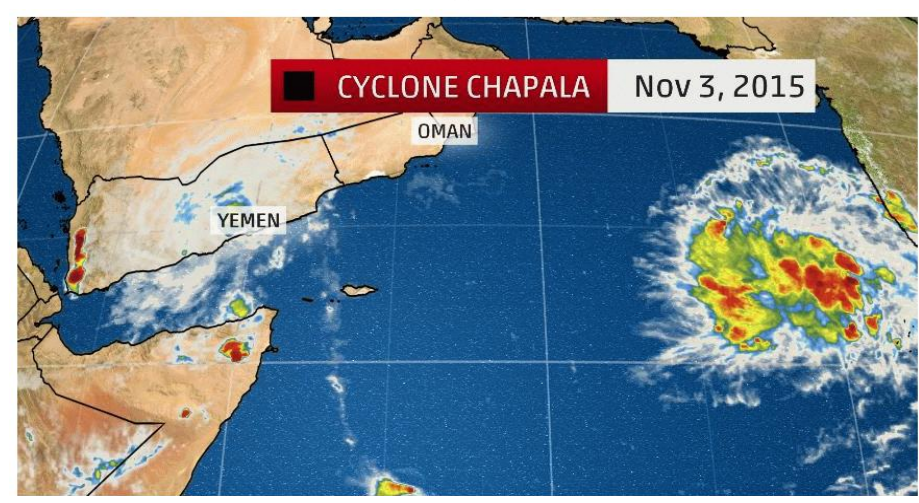

(g)

Figure1. The daily track of hurricane Chapala over the Arabian Sea. [Infrared satellite history of Cyclone Chapala].

[Source: https://weather.com/storms/hurricane/news/cyclone-chapala-yemen-oman-arabian-peninsula]

\section{RESUlts AND DiscuSSION}

\subsection{Variability of Weather Conditions Over the Indian Ocean}

The daily data of the meteorological parameters over the Indian ocean through the period 28 October - 3 November 2015 used to study the weather condition variability over the Indian ocean. The anomaly method has been used for this purpose. The results revealed that:-

1- For all the period of hurricane Chapala, a seven days (28 Oct. 2015 -3 Nov. 2015), it is found that there is a high positive anomaly of sea surface temperature (SST), surface air temperature (SAT), precipitation rate (PRE), wind vector (WV), and meridional wind (MW) values. As shown in Table (1).

2- For that period it became clear that there is a significant negative anomaly of sea level pressure (MSLP), zonal wind (ZW), stream function (SF) and out long radiation (OLR) values. As clear from table (1).

3- Figure (2) shows that there is a strong decrease in OLR values over the Indian ocean through the period of (28 Oct. 2015 -3 Nov. 2015).

\subsection{Variability of the OLR over the Indian ocean during period (28 October -3 November 2015)}

In the present study, the daily ITCZ activities are presented by gridded daily OLR data. This data is $\left(2.5^{\circ} \mathrm{X} 2.5^{\circ}\right)$ supported from NCAR with sophisticated spatial and temporal interpolation (Liebmann and Smith, 1996). The results revealed that there is a strong decrease in OLR values through the period of (28 Oct. 2015 -3 Nov. 2015). It is clear that for the study period OLR values have a significant negative anomaly over the Indian ocean. The maximum negative anomaly of OLR is reached to $\left(-120 \mathrm{w} / \mathrm{m}^{2}\right)$ for the days of 28, 29, 31 of October 2015 and 3 November 2015. As a result, that the ITCZ over the Indian ocean is very active through the period of hurricane Chapala over the Arabian sea. See Figure (2) and Table (1). 

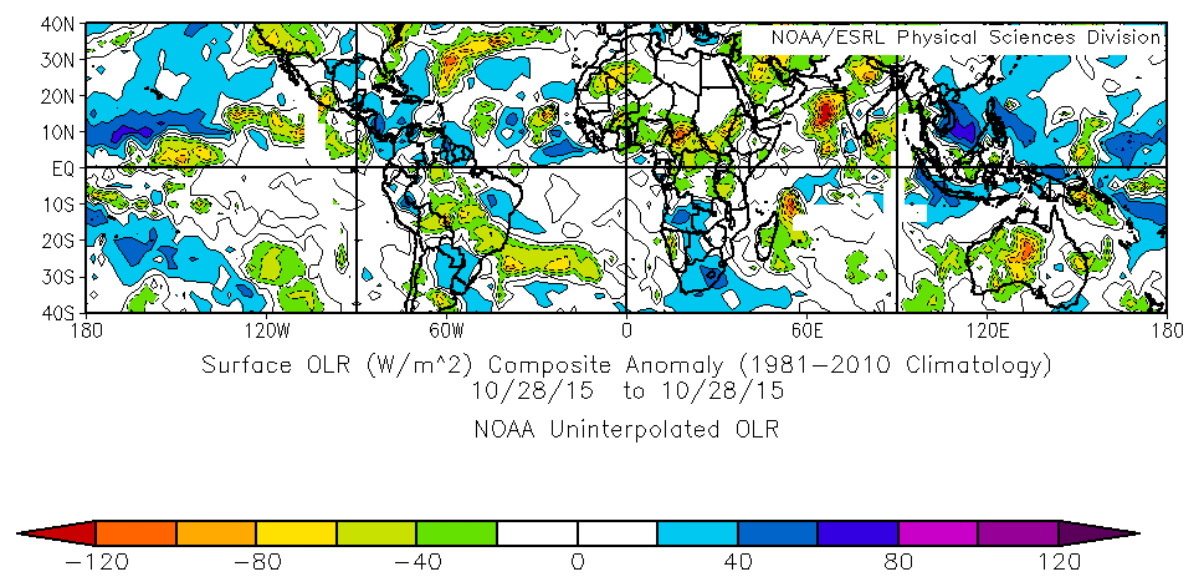

(a)
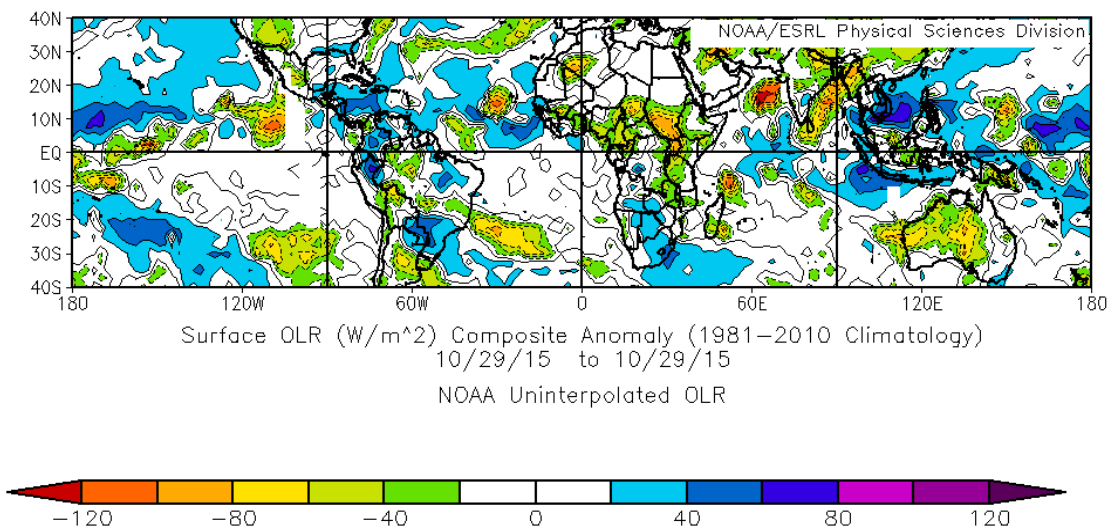

(b)
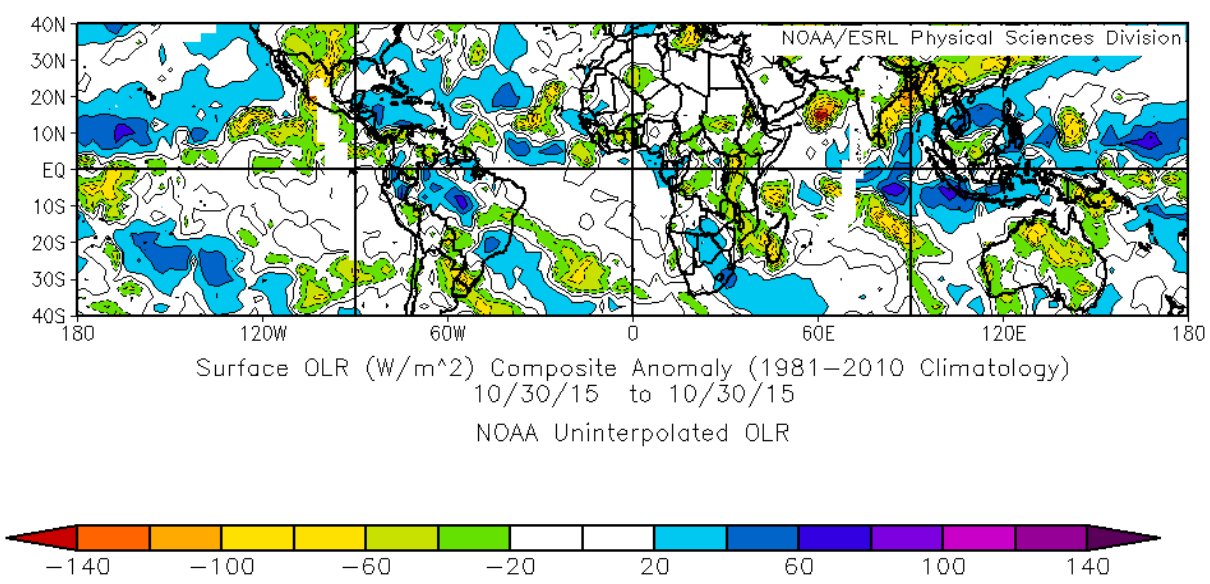

(c)
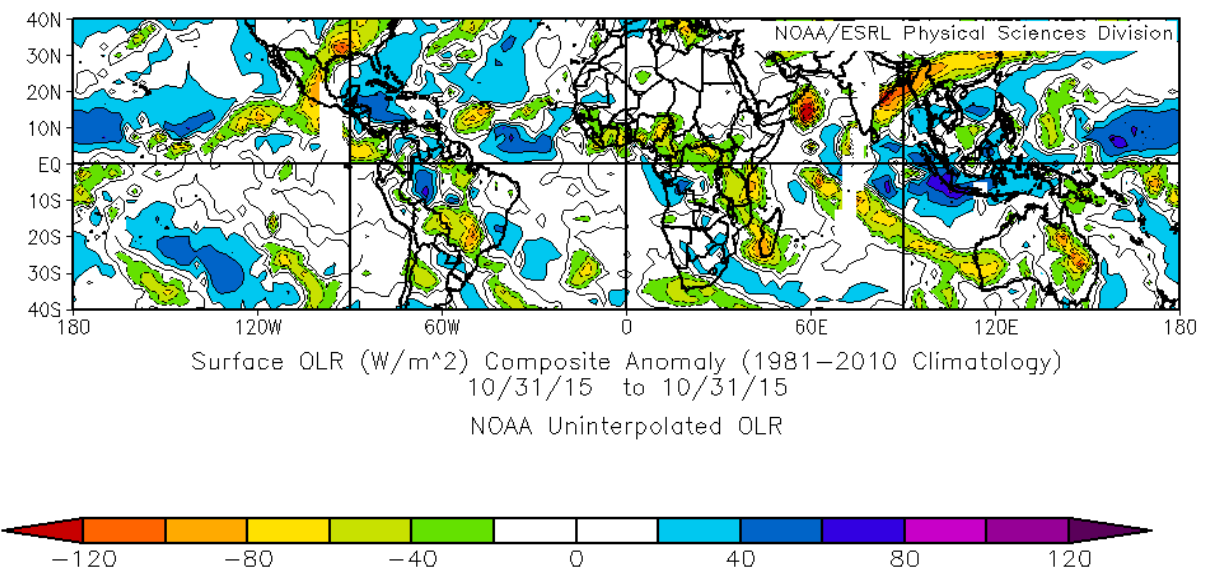

(d) 

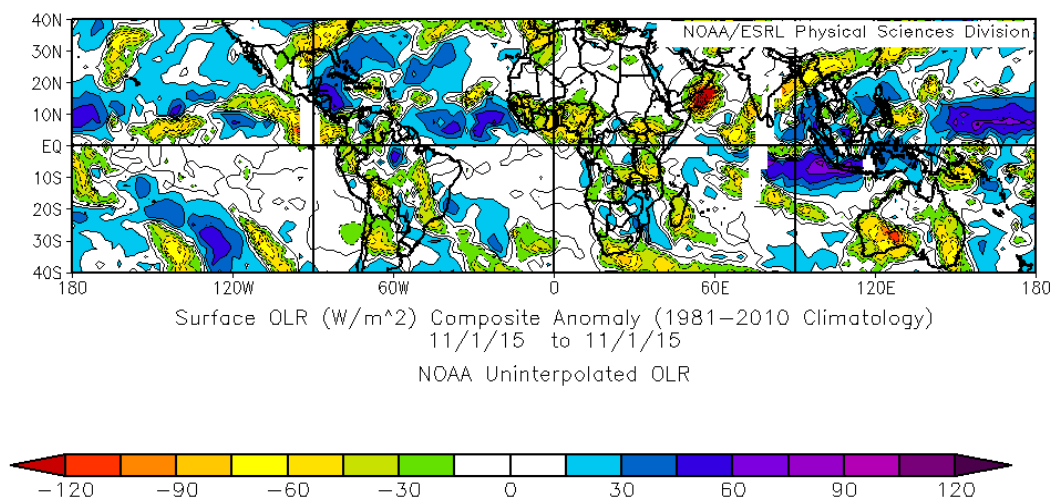

(e)
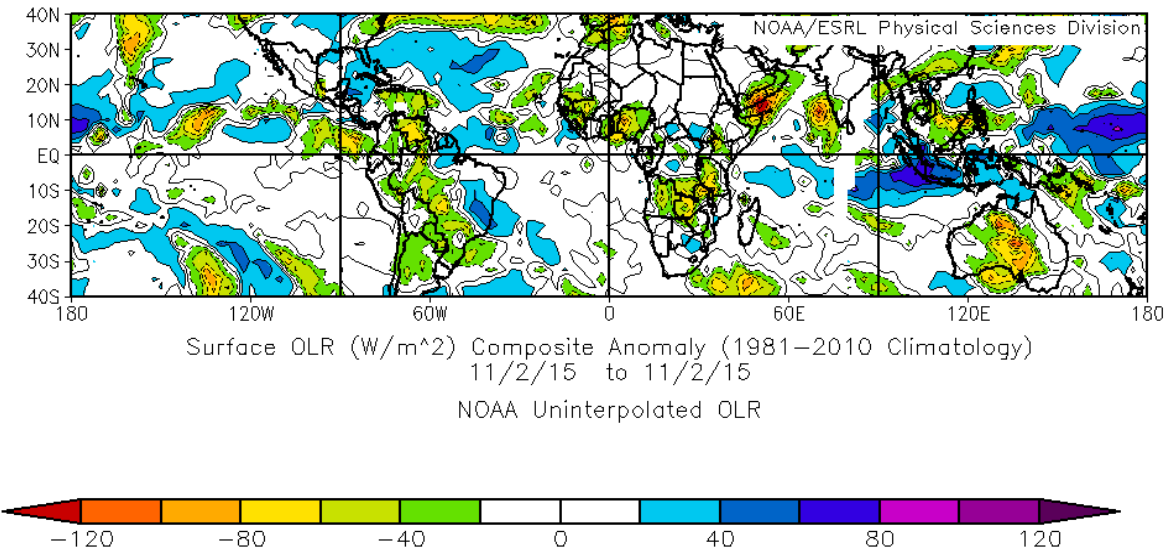

(f)
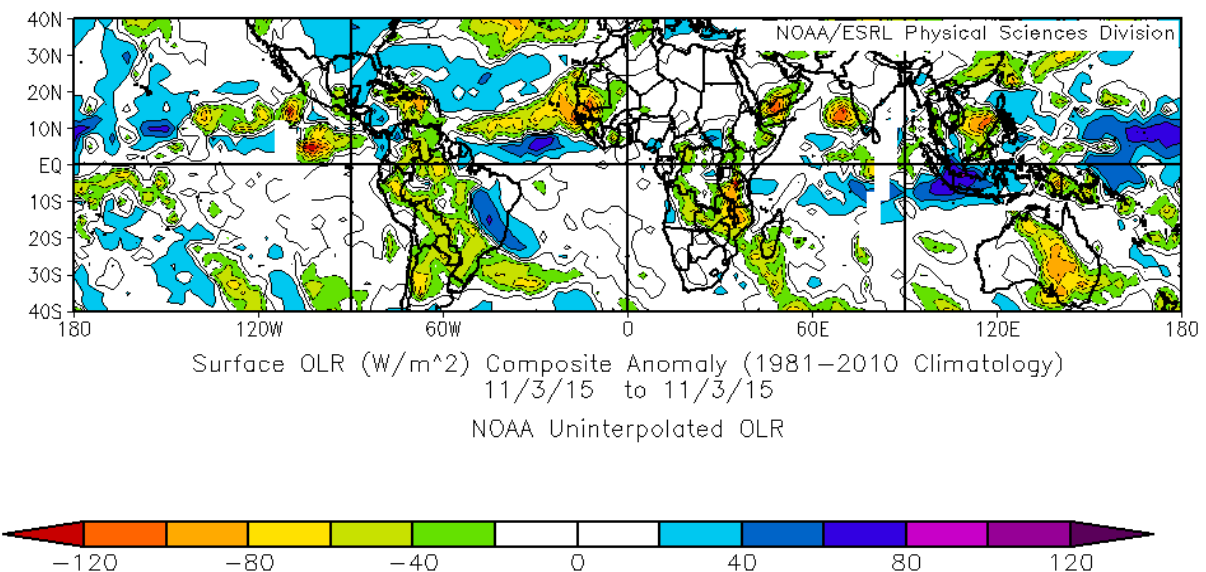

$(\mathrm{g})$

Figure2. The daily distribution of OLR anomaly over the tropical region, including the Indian ocean and Arabian sea through the period of hurricane Chapala (28 October 2015 - 3 November 2015)

Table1. The anomaly of meteorological parameters over the Indian Ocean through the period of hurricane Chapala (28 October 2015 - 3 November 2015)

\begin{tabular}{|c|c|c|c|c|c|c|c|c|c|}
\hline $\begin{array}{c}\text { Meteorlogical } \\
\text { Parameter } \\
\text { Date }\end{array}$ & $\begin{array}{c}\text { SST } \\
\left({ }^{\mathbf{0}} \mathbf{C}\right)\end{array}$ & $\begin{array}{c}\text { SAT } \\
\left({ }^{\mathbf{o}} \mathbf{C}\right)\end{array}$ & $\begin{array}{c}\mathbf{M S L P} \\
\mathbf{( h P a})\end{array}$ & $\begin{array}{c}\text { PRE } \\
(\mathbf{m m} / \mathbf{d a y})\end{array}$ & $\begin{array}{c}\mathbf{V W} \\
(\mathbf{m} / \mathbf{s})\end{array}$ & $\begin{array}{c}\mathbf{M W} \\
(\mathbf{m} / \mathbf{s})\end{array}$ & $\begin{array}{c}\mathbf{Z W} \\
(\mathbf{m} / \mathbf{s})\end{array}$ & $\begin{array}{c}\mathbf{S F} \\
\left(\mathbf{m}^{\mathbf{2}} / \mathbf{s}\right)\end{array}$ & $\begin{array}{c}\text { OLR } \\
\left(\mathbf{w} / \mathbf{m}^{\mathbf{2}}\right)\end{array}$ \\
\hline 28 October 2015 & +1.5 & +2.0 & 0 & +10 & +6 & +9 & -6 & 0 & -120 \\
\hline 29 October 2015 & +1.5 & +2.0 & 0 & +20 & +8 & +10 & -6 & $-1 \mathrm{e}^{+7}$ & -120 \\
\hline 30 October 2015 & +1.5 & +2.0 & -3 & -10 & +8 & +8 & -6 & $-1.5 \mathrm{e}^{+7}$ & -100 \\
\hline 31 October 2015 & +1.0 & +2.0 & 0 & +20 & +8 & +4 & -6 & $-0.5 \mathrm{e}^{+6}$ & -120 \\
\hline 1 November 2015 & +2 & +2.0 & 0 & +20 & +6 & +6 & -7.5 & $-1 \mathrm{e}^{+7}$ & -90 \\
\hline 2 November 2015 & +2 & +2.0 & 0 & +10 & +8 & -5 & -9 & $-0.5 \mathrm{e}^{+6}$ & -80 \\
\hline 3 November 2015 & +2 & +2.0 & 0 & +10 & +8 & -5 & -9 & 0 & -120 \\
\hline All the period & +1.5 & +2.0 & -1.5 & +7 & +4.5 & +4 & -6 & $-1 \mathrm{e}^{+7}$ & -80 \\
\hline
\end{tabular}




\subsection{The relationship between Hurricane Chapala development and weather variability over The Indian Ocean}

Through this section, the linear correlation coefficient technique has used to study the relationship between the development of hurricane Chapala and the weather conditions over the Indian Ocean through the period (28 October 2015 - 3 November 2015). The results revealed that:-

1- There are an outstanding negative correlation coefficient of (-0.96) between the maximum wind of Chapala and the stream function over the Indian Ocean through the study period. As shown in Table (2).

2- There exist an outstanding negative relationship with coefficient $(-0.82)$ between the sea surface temperature and zonal wind over the Indian ocean through the period of study. As illustrated in Table (2).

3 - It becomes clear that there is a strong positive correlation $(+0.88)$ between sea level pressure and precipitation rate as shown in Table (2).

4- In addition to that, there is a very high positive correlation $(+0.91)$ between the zonal wind and meridional wind through the period of hurricane Chapala see Table (2).

5 - There is a direct correlation coefficient of $(+0.34)$ between the out long wave radiation and the maximum wind of hurricane Chapala as shown in Table (2).

Table2. Correlation coefficient matrix between the maximum wind speed of hurricane Chapala and meteorological elements over the Indian ocean through the period (28 October 2015 - 3 November 2015).

\begin{tabular}{|c|c|c|c|c|c|c|c|c|c|c|}
\hline $\begin{array}{c}\text { Corr. Coef. } \\
\text { between the } \\
\text { meteorological } \\
\text { parameters }\end{array}$ & $\begin{array}{c}\text { WIND OF } \\
\text { CHAPALA }\end{array}$ & SST & SAT & SLP & PRE & VW & MW & ZW & SF & OLR \\
\hline $\begin{array}{c}\text { WIND OF } \\
\text { CHAPALA }\end{array}$ & 1 & -0.28 & - & -0.53 & -0.19 & 0.24 & 0.18 & 0.26 & $\mathbf{- 0 . 9 6}$ & 0.34 \\
\hline SST & -0.28 & 1 & & 0.16 & -0.05 & -0.19 & -0.54 & $-\mathbf{0 . 8 2}$ & 0.30 & 0.52 \\
\hline SAT & & & & & & & & & & \\
\hline MSLP & -0.53 & 0.16 & & 1 & $\mathbf{0 . 8 8 *}$ & -0.25 & -0.28 & -0.33 & & \\
\hline PRE & -0.19 & -0.05 & & $\mathbf{0 . 8 8}$ & 1 & -0.22 & 0.00 & -0.04 & -0.57 & -0.33 \\
\hline VW & 0.24 & -0.19 & & -0.25 & -0.22 & 1 & -0.39 & -0.15 & -0.57 & 0.33 \\
\hline MW & 0.18 & -0.54 & & -0.28 & 0.00 & -0.39 & 1 & $\mathbf{0 . 9 1}$ & 0.20 & -0.55 \\
\hline ZW & 0.26 & $-\mathbf{0 . 8 2}$ & & -0.33 & -0.04 & -0.15 & $\mathbf{0 . 9 1}$ & 1 & 0.00 & -0.57 \\
\hline SF & $\mathbf{- 0 . 9 6}$ & 0.30 & & & -0.57 & -0.57 & 0.20 & 0.00 & 1 & -0.57 \\
\hline OLR & 0.34 & 0.52 & & & -0.33 & 0.33 & -0.55 & -0.57 & -0.57 & 1 \\
\hline
\end{tabular}

Whereas;

*: significant level of $99 \%$

**: significant level of $95 \%$

-----: Means no significant variation of the parameter through that period

Hurricane frequencies and activities are increased in the Arabian sea through the last two decades. Hurricane Chapala is a strong one of them that landfall Yemen and cause big damage and disaster. Through the present work daily data of the meteorological parameters over the Indian ocean has analyzed to reach to the cause of the development of hurricane Chapala through the period of 28 October 2015 to 3 November 2015. The anomaly and correlation coefficients techniques have been used to reach this goal. The results revealed that almost of the meteorological parameters record an extreme value. Moreover, there are abnormal weather conditions existed in the region of the Indian ocean. It is found that there is a high positive anomaly of SST, SAT, PRE, WV, and MW values. Through the period of hurricane Chapala, it became clear that there is a significant negative anomaly of the MSLP, ZW, SF and OLR values. The correlation coefficient analysis clarifies that there are an outstanding negative correlation coefficient of $(-0.96)$ between the maximum wind of hurricane Chapala and the stream function over the Indian ocean. The stream function analysis is a very important factor to discover the dynamics of airflow in the Indian Ocean through the duration of hurricane Chapala. These results showed that the anomaly of the forces and wind directions over the 
Indian Ocean has existed at that time. Moreover, a strong negative relationship appeared between the SST and ZW the period of study. There is a significant direct correlation between MSLP and PRE over the Arabian Sea. In addition, there is an outstanding positive, high correlation between the ZW and MW. The extremes anomaly of $\mathrm{ZW}$ and MW create a rotation and form the hurricane Chapala over Arabian Sea.

\section{Conclusions}

Hurricane frequencies and activities are increased in the Arabian sea through the last two decades. Hurricane Chapala is a strong one of them that landfall Yemen and cause big damage and disaster. Finally, one can conclude that the abnormal extreme weather conditions over the Indian Ocean are playing a great role in creating and develop hurricane Chapala over the Arabian Sea.

\section{ACKNOWLEDGEMENTS}

Author hopes to thank the Climate Diagnostics Centre for supporting the data. Whereas, the plots and images were provided by the NOAA-CIRES Climate Diagnostics Centre, Boulder, Colorado, the USA. Also, thanks to the Indian Meteorological Department and the Joint Typhoon Warning Center JTWC) for supporting data.

\section{REFERENCES}

Atkinson, G. D. (1971) Forecasters' Guide to Tropical Meteorology. University Press of the Pacific, Honolulu.

Annual Tropical Cyclone Report (2016) United States Joint Typhoon Warning Center. Archived from the original (PDF) on September 11, 2015. Retrieved July 11, 2016.

Bates, J. R., (1970) Dynamics of Disturbances on the Intertropical Convergence Zone, Quart., J. R. Met. Soc., 96, 677-701.

Broccoli, A. J., Dahl, K. A., and Stouffer, R. J. (2006) Response of the ITCZ to Northern Hemisphere cooling, Geophys. Res. Lett., 33, L01702, doi: 10.1029/2005GL024546.

Citeau, J., Berges, J. C., Demarcq, H. and Mahe, G., (1988b). The Watch of ITCZ Migrations over Tropical Atlantic as an Indicator in Drought Forecast over Sahelian area. Ocean-Atmos. News. (45):1-3.

Chiang, J. C. H., and Friedman, A. R., (2012) Extratropical cooling, interhemispheric thermal gradients, and tropical climate change, Annu. Rev. Earth Planet. Sci., 40, 383-412.

Cohen, J., Saito, K., and Entekhabi, D., (2001) The Role of the Siberian High in Northern Hemisphere Climate Variability. Geophys. Res. Let., 28, 2, 299-302.

El Rafy M., and Hafez Y. (2008) Anomalies in meteorological fields over northern Asia and it's impact on hurricane Gonu. AMS, Conference on Hurricanes and Tropical Meteorology. 28 April - 2 May 2008, Orlando, FL, AMS, USA.

Evan, A. T.,and Camargo, S. J. (2011) A Climatology of Arabian Sea Cyclonic Storms. Journal of climate, 24, 140-158, DOI: 10.1175/2010JCLI3611.1.

Frierson, D. M. W., and Huang, Y. T. (2012) Extratropical influence on ITCZ shifts in slab ocean simulations of global warming, Climate, 25, 720-733.

Gadgil, S. and Guruprasad A. (1990) An objective method for the identification of the Intertropical Convergence Zone. Journal of climate, 3, 558-567.

Hafez Y. Y, and M. Almazroui (2016) Study of the relationship between African ITCZ variability and an extreme heat wave on Egypt in summer 2015. Arabian Journal of Geosciences. Volume 9; doi: 10.1007/s12517-016-2497-4.

Hafez, Y. (2012) Variability of Intertropical Convergence Zone (ITCZ) and Extreme Weather Events, Atmospheric Model Applications, Dr. Ismail Yucel (Ed.), InTech, DOI: 10.5772/33809.

Hafez, Y.Y., (2007) The Connection Between the 500 hpa Geopotential Height Anomalies over Europe and the Abnormal Weather in Eastern Mediterranean During Winter 2006. I. J. Meteorology, UK, 32, 324, 335-343.

Hafez, Y. Y., (2003) Changes in Atlantic - Western Africa ITCZ Variability and Its Influence on the Precipitation Rate in Europe on Sever Rainy Summer 2002. J. Meteorology, U.K., 28, 282, 299307. 
Hess, P. G., Batissti, D. S. and Rasch, P. J., (1993) Maintenance of the Intertropical Convergence Zones and the Large-Scale Tropical Circulation on a Water Covered Earth. J. Atmos. Sci., 50, 691-713.

Joint Typhoon Warning Center (2015) Tropical Cyclone 04A (Chapala) Warning \#08. Accessed October 30, 2015.

Jury, M. R., Parker, B. and Waliser, D. (1994) Evolution and variability of the ITCZ in the SW Indian Ocean: 1988-1990.Theor. Appl. Climatol., 48, 187-194.

Kalnay, E., Kanamitsu, M., Kistler, R., et al., (1996) The NCEP/NCAR 40-year reanalysis project[J]. Bull. Amer. Meteor. Soc., 77, 437-470.

Kang, S. M., Held, I. M. Frierson, D. M. W. et al., (2008) The response of the ITCZ to extratropical thermal forcing: Idealized slab-ocean experiments with a GCM. J. Climate,21, 3521-3532.

Kendall M. G. and Stuart A (1973) The advanced theory of statistics, volume 2: inference and relationship, Griffin. ISBN 0-85264-215-6.

Kraus, E. B., (1997) The Seasonal Excursions of the Intertropical Convergence Zone. Mon. Wea. Rev., 105, 1009-1018.

Liebmann, B., and C. Smith, A. (1996) Description of a complete (Interpolated) outgoing longwave radiation dataset, Bull. Amer. Meteor. Soc., 77, 1275-1277.

Philander, S. G. H., Gu, D., Lambert, G., Lau, N.C., Li, T. \& Pacanows, R. C., (1996). Why the ITCZ is Mostly North of the Equator. J. Climate, 9, 2958-2972.

Pike, A. C., (1972) The Inter-Tropical Convergence Zone Studied with an Interacting Atmosphere Ocean Model. Mon. Wea. Rev., 99, 469-477.

Raymond, D. J., Bretherton, C. S., \& Molinari, J., (2006). Dynamics of the Intertropical Convergence Zone of the East Pacific. J. Atmo. Sci., 63, 2, 582-597.

Rosting, B., and Kristjansson, (2008) A Successful Resimulation of the 7-8 January 2005 Winter Storm Through Initial Potential Vorticity Modification in Sensitive Regions. Tellus A, 60, 4, 604-619.

Saffir, H. S. (1973) Hurricane wind and storm surge. Military Engineer, 423:4-5.

Sato, N., Yoneyama, K. Katsumata, M. Shirooka, R.and Takayabu Y. N. (2007) An ITCZ-like convergence zone over the Indian Ocean in boreal late autumn, Geophys. Res. Lett., 34, L10811, doi:10.1029/2006GL028341.

Simpson, R. H. (1974) The hurricane disaster potential scale. Weatherwise, 27:169-186.

Schott, F. A., Xie, S.-P. and McCreary Jr, P. (2009) Indian Ocean circulation and climate variability, Rev. Geophys. ,47, RG1002, doi:10.1029/2007RG000245.

Sultan, B. and Janicot, S., (2000) Abrupt Shift of the ITCZ over West Africa and Intra-Seasonal Variability. Geo. Res. Let, 27, 3353-3356.

Vialard, J., Terray, P. Duvel, J.-P. et al., (2011) Factors controlling January-April rainfall over southern India and Sri Lanka,Climate Dyn., 37, 493-507, doi:10.1007/s00382-010-0970-4.

Waliser, D. E.,and Somerville, C. J., (1994) Preferred Latitudes of the Intertropical Convergence Zone. J. Atmos. Sci., 51, 1619-1639.

Waliser, D. E., (1992) The Preferred Latitudes of the Intertropical Convergence Zone: Observations and Theory. Ph. D. Dissertation, Scripps Institution of Oceanography, University of California, San Diego.

Xie, S. P., and Philander S. G. H., (1994) A coupled ocean-atmosphere model of relevance to the ITCZ in the eastern Pacific. Tellus, 46A, 340-350. 


\section{AUTHOR'S BIOGRAPHY}

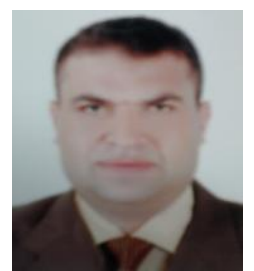

Professor Yehia Hafez, is a Prof. of Meteorology, at King Abdulaziz University, Department of meteorology, Faculty of Meteorology and Environment KSA since 2012. Prof. of meteorology in Cairo University, Egypt since 2008.The main field of research is the atmospheric science and meteorology. The main specific topic is the synoptic meteorology and blocking systems. Has experiences more than 25 years in meteorology and climatic studies. Published more than 30 papers through regional and international journals. Teaching all meteorology courses (synoptic, dynamical, weather forecast, etc). Has Bsc in physics in 1986 from Ain shams University, Diploma in Meteorology, 1992 from Cairo University. MSc in meteorology in 1995 from Cairo University and $\mathrm{PhD}$ in meteorology from Cairo University in 1997. Editor in several international scientific journals since 2012. International expert in IPCC for climatic change report. Reviewer for several international scientific journals. Also Director of international Egyptian ozone unit and in UNIDO for the period 2003-2005. Head of meteorology department in civil aviation technical college, sebba, Libya 2009-2010. 